\title{
Carbon Accounting Reflection as a Response to Face the Climate Change
}

\author{
Prof. Dr. Sri Iswati, CA \\ Director of Postgraduate School \\ Universitas Airlangga \\ Surabaya, Indonesia \\ Email : iswati@feb.unair.ac.id; iswati.feua@gmail.com
}

\begin{abstract}
Climate change has been a global issue in the $21^{\text {st }}$ century. Climate change is the inevitable impact of the rapid development of industrial world and the fast growing of technology in the $21^{\text {st }}$ century. A change in climate around the world is the trigger for global warming. The negative effect of global warming could be catastrophic for human kind. This paper is aimed at sharing a provoking thought on solutions for the business world to face the impact of global warming that can damage the environment and become a disaster for humans. Carbon-accounting is an alternatively offered to industrial and management as a response to this natural phenomenon.
\end{abstract}

Key words-climate change, global warming, carbonaccounting, industrial-manufacturing

\section{INTRODUCTION}

The development of technology and the rise of industry are the inevitable situation of the 21 st century. The very real impact of both situations is on the environment. Lately there is often a flood disaster that is almost evenly distributed throughout the world, not to mention landslides or other natural disasters. Indirectly, these disasters are the result of climate change in the world. Climate change is what causes global warming happening around the world.

\section{Why carbon-accounting exists}

Global warming, climate change, environmental damage, decreasing natural resources availability, that is a very influencing issue to the companies. The fact about business activity which significantly affected to economy is real, although the effect to the environment and society can't be less striking. For example, what recently happened was hail in Bandung, West Java, Indonesia, tsunami, landslide, dry weather and the unpredictable rainy season.

Global warming is the increase in the average temperature of the earth's surface due to an increase in the amount of greenhouse gas emissions in the atmosphere. Global warming will be followed by climate change.

Climate change is a long-term change, in the distribution of weather patterns statistically over a period of time from decades to millions of years. This term may also mean changes, it means as well weather conditions or changes in the distribution of average weather events, for example, the number of extreme weather events that are increasingly or slightly smaller. Climate change is limited to a specific region or can occur in all regions of the Earth (https://en.wikipedia.org/wiki/Perubahan_iklim).

IPCC (2001) states that climate change refers to the average variation in a place's climatic conditions or to its statistically significant variability for long periods of time (usually decades or more). It is also clarified that climate change may occur due to internal natural processes as well as external forces, or human activities that are constantly changing atmospheric composition or land use.

Global Warming and Climate Change are the result of human activities, especially those related to the use of fossil fuels (petroleum and coal) as well as other activities related to forests, agriculture, and livestock. Human activity in these activities directly or indirectly causes a change in the natural composition of the atmosphere, namely the increase in the amount of greenhouse gases globally.

Global warming is the increase in the average temperature of the atmosphere, the earth, and the oceans. While climate change is a significant change in climate, such as air temperature or rainfall, over a period of 30 years or more. Climate change is a projection of the continuation of global warming.(Https://alamendah.org/2013/04/24/mengen al-pemanasan-global-dan-perubahan-iklim/)

The greenhouse is an analogue of the Earth surrounded by glass cups. In fact what happens is to take it into the earth's atmosphere covered with gas. At the time of sunlight into the earth then it must penetrate the gas/glass in the form of radiation. The rays are partially absorbed by the earth and some will be reflected back into space. Like the greenhouse process in the agricultural industry, this greenhouse is used to warm the temperature, so the plants can thrive. The problem is, when high human activity causes an increase in the thickness of the gas blanket in the atmosphere (greenhouse gases). As a result, the heat of the sun can not be reflected back perfectly, this is called the greenhouse effect. 
There are six gases included in greenhouse gas. The following list based on the biggest contribution the greenhouse gas, are: 1) carbon dioxide (CO2), 2) methane $(\mathrm{CH} 4), 3)$ dinitro oxide $(\mathrm{N} 2 \mathrm{O})$, those three substances driven by fossil energy resources, deforestation and agriculture. Next 4) hydrofluorocarbons (HFC), 5) perfluorocarbons (PFC), 6) sulphur hexafluoride (SF6) are only contribute $1 \%$.

The largest sources of $\mathrm{CO} 2$ are coal-fired power plants, motor vehicles, fossil-based energy industries. Based on this fact the management accountants should start thinking about how to manage carbon extraction within the company. This issue makes the role of environmental accounting stronger, especially in reducing the amount of carbon in the industry better known as carbon-accounting.

\section{The role of carbon-acconting in facing global warming}

Carbon-accounting refers generally to processes undertaken to "measure" amounts of carbon dioxide equivalents emitted by an entity. It is used inter alia by nation, states, corporation, individuals to create the carbon credit commodity traded on carbon markets (or to establish the demand for carbon credits). Correspondingly, examples for products based upon forms of carbon accounting can be found national inventories, corporate environmental reports or carbon footprint calculators. Likening sustainability measurement, as an instance of ecological modernisation discourses and policy, carbon accounting is hoped to provide a factual ground for carbon-related decision-making. However, social scientific studies of accounting challenge this hope (Lohman, 2009) pointing to the socially constructed character of carbon conversion factors (McKenzie, 2009) or of the accountants' work practice (Lippert, 2012) which cannot implement abstract accounting schemes into reality.(https://en.wikipedia.org/wiki/carbon_accounti ng)

In 1993 the United Nations issued the Handbook of National Accounting: System for Integrated Environmental and Economic Accounting (SEEA), during an international workshop organized by the United Nations Environment Program (UNEP) and the World Bank. The SEEA publications are directed to provide a framework for presenting information related to the environment and its impact on the economy.

In 2003 the SEEA was revised. The framework of this report is used as a guide to disclose information on institutional sustainability to the public. The drafting process of this framework involves more than
60 countries consisting of companies, public, academia, workers, and professional institutions.

The Kyoto Protocol is an international amendment on climate change. Countries that have ratified it are committed to reducing carbon dioxide and other greenhouse gas emissions. This Protocol was ratified by 181 States, signed on 11 December 1997 and entered into force on 16 February 2005. The official name of this agreement is "Kyoto Protocol to the United Nations Framework Convention on Climate Change (UNFCCC)" (Wikipedia.org/wiki/Protokol_Kyoto).

Sustainability report is a report published by the company to reveal the company's performance from economic, environmental and social aspects, better known as the concept of triple bottom line (people, planet, profit). This report is prepared under the Sustainability Reporting Guidelines (SRG) guidelines issued by the Global Reporting Initiative (GRI). This report has 3 principles, namely: accuracy, completeness, and reliability. The contents of SRG generally consist of: 1) Company Profile, 2) Report Profile, 3) Scope, 4) GCG, 5) Stakeholder Engagement, 6) Environmental Performance Indicators, 7) Employment and Human Resources, 8) Consumer.

From the previous description, it can be seen that the company / industry is one of the largest $\mathrm{CO} 2$ (carbon dioxide) estimates. Awareness of the need to commit to reduce gas emissions to save the world starts from the Kyoto Protocol. The company's commitment is demonstrated by the Sustainability report, which is the company's commitment to the economy, environment and social.

In Indonesia, regulations related to the implementation and disclosure of sustainable businesses include:

1) Bappepam regulations requiring disclosure of CSR activities in annual reports since 2005

2) Inc. (Incorporated)/Ltd. (Limited Liability Company) Act No. 40 of 2007

All BUMN are required to allocate $1-3 \%$ of net income to finance community development programs and submit separate audited reports. Indonesia also has an Appraisal of Corporate Performance Rating in Environmental Management called PROPER. The legal basis is the Decree of the Minister of Environment No. 127 / MENLH / 2002 on the Corporate Performance Rating Program in Environmental Management. In practice, PROPER uses Environmental Performance Indicators (EPI) and is defined based on context and content according to the assessed company. PROPER performance ratings are ranked in five colors: Gold, Green, Blue, Red and Black. 


\section{The readiness of industries managing carbon- accounting}

In conjunction with accounting, carbon cost management is a new era in the idea of economic transactions based on ecology, which we call carbonaccounting. Some research on carbon-accounting in Indonesia shows the following results: Ja'far and Yogi (2009) who conduct research on manufacturing companies, show that: (1) The quality of awareness of the environment at the company is low, (2) Already have efforts to efficiency carbon emissions, (3) Need to be designed development of carbon accounting standards, (4) Carbon management reporting can be used as a measure of environmental performance. In addition, Ja'far and Kartikasari (2009) state that industry actors require accounting standards for carbon.

Carbon-accounting is the process of calculating the amount of carbon released by industrial processes, reduction targets, the establishment of systems and programs to reduce carbon emissions, and reporting on the progress of the program (Louis et al., 2010). With carbon accounting, companies can know the level of carbon emissions it produces from the measurement results, then the company's management can establish strategies to reduce carbon emissions and report it to the company's stakeholders. Carbon-accounting will encourage companies to reduce carbon emissions levels (Zvezdov, Dimitar and Stefan Schaltegger, 2015).

In a case study conducted by Delphine Gibassier and Stefan Schaltegger (2015) demonstrates that it is possible to connect two carbon management accounting approaches focusing on products and the organization into a combined carbon management accounting system. This has potential impact in making carbon management accounting in organizations leaner, and more efficient in terms of performance measurement and external communication.

Finally, a simple research conducted by the author in April - May 2017 on private enterprise managers shows that managers generally understand and understand and feel the climate change, they have also allocated funds to manage the environment, but in general they have never Heard about carbonaccounting.

Based on the results of the research presented in Section 3 of this paper, it can be said that Carbonaccounting becomes an inevitable requirement. The triggers include waste $\&$ carbon emissions generated by industry increasingly a real cause for global warming which in turn causes climate change. To provide understanding and understanding of the importance of carbon-accounting, it is necessary to socialize the company's managers in the form of seminars or workshops. Also more research is required to produce popular scientific and writing papers on the media. In addition, to encourage carbon-accounting, it is necessary to support the carbon accounting standard as the foundation of transparency and accountability in the implementation of carbon-management reporting.

\section{CONCLUSIONS}

As global warming has sequential impact onclimate change and environmental damage then in turn will influence ondecreasing in natural resources availability. One of the elements that contribute to global warming is manufacturing. Therefore, to face the climate change should face by implementing carbon-accounting which include these steps, namely:

1) Global Warming and Climate Change are the result of human activities, related to the use of fossil fuels, and other activities related to forests, agriculture, and livestock. Human activity in these activities directly or indirectly causes a change in the natural composition of the atmosphere, namely the increase in the amount of greenhouse gases globally.

2) Regulations related to the implementation of sustainability report for companies in Indonesia, namely:

a. Bappepam regulation that requires disclosure of CSR activities in annual reports since 2005

b. Act No. 40 of 2007 PT

c. All SOEs are required to allocate 1-3\% of net income to finance community development programs and submit a separate, audited report.

3) Rating of the Company's Performance Rating in Environmental Management in Indonesia is called PROPER. The legal basis is the Decree of the Minister of Environment No. 127 / MENLH / 2002.

4) Carbon-accounting will encourage companies to reduce carbon emissions levels.

5) Required accounting tools that can be used to implement carbon-accounting.

\section{References}

Carbon Accounting, https://en.wikipedia.org/wiki/Carbon accounting

Delphine Gibassier, Stefan Schaltegger, 2015. "Carbon management accounting and reporting in practice: A case study on converging emergent approaches", Sustainability Accounting, Management and Policy Journal, Vol. 6 Issue: 3, pp.340-365, doi: 10.1108/SAMPJ-02-20150014 
Ja'far, Muhammad Shodiq, danYogi Trisita Febri, 2009. "Sistem Akuntansi dan Pelaporan Emisi Karbon: Dasar Pengembangan Standar Akuntansi Karbon (Studi Ekspolrasi pada Perusahaan Manufaktur di BEI)", Universitas Islam Sultan Agung

Ja'far, Muhammad Shodiq, dan L Kartikasari, 2009, "Need Assesments: Standar Akuntansi Carbon dan Praktik Carbon Accounting", Palembang: SNA 12

Lippert, I. 2012. Extended carbon cognition as a machine. Computational Culture, 1(1), 2011. and Lippert. Carbon classified? Unpacking heterogeneous relations inscribed into corporate carbon emissions. Ephemera, 12(1/2):138-161, 2012.

Lippert, I. 2013. Enacting Environments: An Ethnography of the Digitalisation and Naturalisation of Emissions. University of Augsburg, 2013.

Lohmann, L. 2009. Toward a different debate in environmental accounting: The cases of carbon and cost-benefit. Accounting, Organizations and Society, 34:499-534, Apr 2009.

Louis, S., I. Raditya, dan Sofian. 2010. "Peran Carbon Accounting dalam Implementasi CorporateSocialResponsibility untuk MengurangiPolusi Industri",MakalahdisampaikanpadaPekan Ilmiah MahasiswaNasional (PIMNAS)keXXIII, Bali.
MacKenzie, D. 2009.Making things the same: Gases, emission rights and the politics of carbon markets. Accounting, Organizations and Society, 34(3-4):440-455, Apr 2009.

Perubahan Iklim, https://en.wikipedia.org/wiki/Perubahan_iklim

Perubahan iklim danglobal warming, https://alamendah.org/2013/04/24/mengenalpemanasan-global-dan-perubahan-iklim/

Sustainability Report, https://ninikamei.wordpress.com/2014/10/10/s ustainability-reporting-sebagai-informasibentuk-pertanggungjawaban-perusahaanterhadap-lingkungan-sosialnya/

United Nation, 1998, “Kyoto Protocol to The United Nation Framework Convention on Climate Change", https://wikipedia.org/wiki/Protokol_Kyoto

Zvezdov, Dimitar and Stefan Schaltegger, 2015. "DecisionSupportThroughCarbon ManagementAccounting-A FrameworkBasedLiteratureReview". Switzerland: SpringerInternationalPublishing.

\section{About the Author:}

Prof. Dr. Sri Iswati, CA., currently is the Director of Postgraduate School, and lecturer at Economic \& Business Faculty of UniversitasAirlangga (UNAIR) in Surabaya, Indonesia. She can be reached at iswati@feb.unair.ac.id, and iswati.feua@gmail.com 